[17] Fittal', R. K., Korol'ova, Zh. V. (2014). Sravnitel'naja ocenka klinicheskoj jeffektivnosti sovremennyh preparatov dlja remineralizirujushhej terapii. Sovremennye problemy nauki i obrazovanija.

[18] Joshi, S., Patil, N., Choudhari, S., Kulkarni, S. (2013). Comparative evaluation of remineralizing potential of three agents on artificially demineralized human enamel: An in vitro study. Journal of Conservative Dentistry, 16 (2), 116. doi: 10.4103/0972-0707.108185

[19] Ranjitkar, S., Rodriguez, J. M., Kaidonis, J. A., Richards, L. C., Townsend, G. C., Bartlett, D. W. (2009). The effect of casein phosphopeptide-amorphous calcium phosphate on erosive enamel and dentine wear by toothbrush abrasion. Journal of Dentistry, 37 (4), 250-254. doi: 10.1016/j.jdent.2008.11.013

[20] Oshiro, M., Yamaguchi, K., Takamizawa, T., Inage, H., Watanabe, T., Irokawa, A. et. al. (2007). Effect of CPP-ACP paste on tooth mineralization: an FE-SEM study. Journal of Oral Science, 49 (2), 115-120. doi: 10.2334 josnusd.49.115

\title{
USE OF METHODS OF MATHEMATIC STATISTICS FOR PROCESSING OF MEDICAL-BIOLOGICAL DATA FOR REVELATION OF THE ROLE OF CHEMICAL ELEMENTS IN ETHIOPATHOGENESIS OF HUMAN DISEASES
}

\author{
Anatolij Prykhodchenko \\ Department of Ecological Management \\ Dneprodzerzhinsk Institute of Economic and Management \\ 9 May str., 18, Dneprodzerzhinsk, Ukraine, 51934 \\ prykhod@mail.ru \\ Yulia Ulianovska \\ Department of Information Systems and Technology \\ University of Customs and Finance \\ 2/4 Vernadskogo str., Dnepropetrovsk, Ukraine, 49000 \\ uyv@rambler.ru \\ Vladislav Ulianoskiy \\ Student of I Medical department \\ Zaporozhye State Medical University \\ 26 Mayakovsky ave., Zaporozhye, Ukraine, 69035 \\ vlad.ulianovskiy@mail.ru
}

\begin{abstract}
Aim of paper was to appraise the possibility of use of the traditional mathematical statistics methods for biomedical data to processing for determining the role of aluminium, chrome, niobium and lead in functioning of human blood-forming system. An effect of the abovementioned microelements on immunocompetent and blast cells was examined.

Methods. To solve the indicated purposes, it were examined the venous blood leukoconcentrate in 48 of the examined persons. The standard methods of statistics were applied to the obtained data, namely the construction of spreading plot, elements of correlation and regression analysis.

Results. It was obtained, that the reaction of immunocompetent and blast cells is ambivalent and depends upon the level of micronutrient status in human organism. Micronutrient biogenic effect is observed upon its low concentration in blood. An abiogenic effect arises upon the high level of micronutrient status in biological media of human.

Conclusions. Notwithstanding the obtained results, the generally accepted approaches haven't provided the possibility to determine the faithful character of immunocompetent and blast cells reaction on the level of micronutrient status in human organism and require the elaboration and development of the new approaches considering the revealed nonlinear relation.
\end{abstract}

Keywords: hematopoietic system, leukoconcentrate venous blood, correlation analysis, regression analysis. 


\section{Introduction}

Environmental situation in Ukraine and in other countries of the world mostly depends on influence of both natural and technogenic factors. Most cities of Ukraine are industrial and very high level of air pollution is typical for them. Thus, for example, according to operational data of MMC enterprises of Kriviy Rig city, emissions of polluting substances in air for 2015 were 15,4 thousand tones, in Dneprodzerzhinsk city it was $500 \mathrm{~kg}$ of industrial emissions for each dweller annually. The control of the level of pollution of agricultural soils, water and products in regions of mines and coal electric stations is topical for determination of concentration of chemical elements in soils and water in direct closeness to electric station [1].

Chemical substances are the part of our everyday life; whole organic and inorganic matter consists of many chemical substances and each produced commodity includes the use of chemical substances. At correct use these chemical substances make significant contribution in improvement of our life quality, health and well-being. At incorrect one - some chemical substances are very dangerous and can influence the human health negatively. The most important polluters of environment in regions with high level of anthropogenic pressure include such heavy metals as cadmium, copper, lead, chromium, mercury. Their presence in environment, even in small amount, can cause serious problems for all organisms. In any regime of entrance in human organism heavy metals are the serious threat for it. The long action of these toxic metals creates harmful effect on health in human organism [2].

In the work [3] is noted, that practically all heavy metals are toxic in sufficient amount. But some of them are specifically interesting because of their concentrations in environment (lead, mercury and arsenic) or their use in criminal poisoning (arsenic and thallium). Metals manifest toxicity at the expense of creation of complexes with cellular compounds that contain sulfur, oxygen or nitrogen. These complexes activate enzyme systems or modify protein structure that leads to cellular dysfunction and death of cells. The central and peripheral nervous systems, cardio-vascular and hematopoietic systems are injured most often.

Bone marrow of the modern human is not evolutionary ready to face many anthropogenic factors and became a trap for heavy, colored, rare earth elements, chemical and radioactive substances. Depositing of stable and radioactive chemical substances leads to the hard interaction of metals and cellular content of marrowy hematosis that, in its turn, is not finally explained in human ethiopathogenesis. The data about mechanisms of interaction in system "microelement-cell" are fragmental.

Chemical elements can penetrate in human blood. Thus, on the Fig. 1 can be seen big fatty cells, surrounded with lymphoid elements. The coal small parts are observed. Heavy metals are highly active and can be embedded in genetic apparatus of cell that has negative influence on marrowy hematosis and system of stem cells.

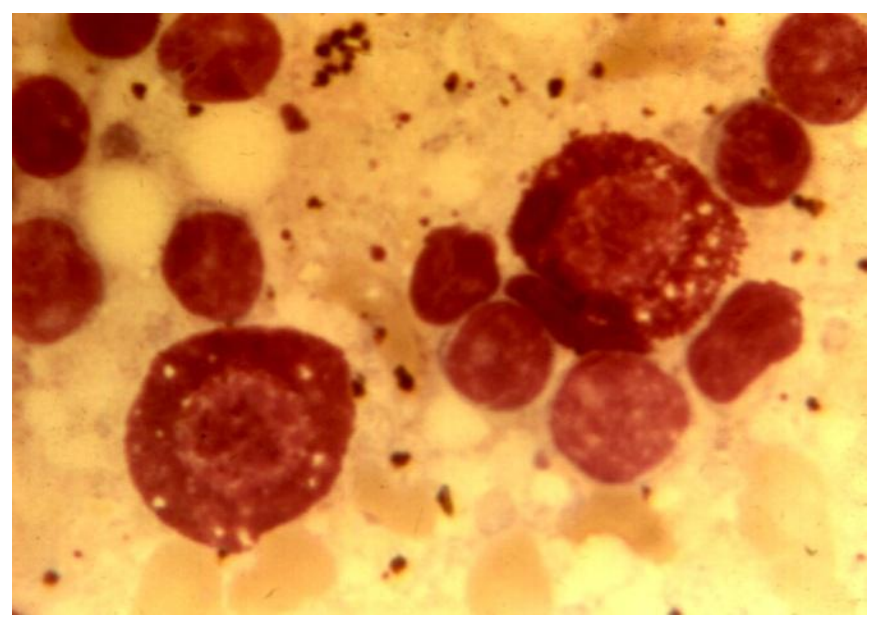

Fig. 1. Smear of print of biopsy material of human lymph node

The one of ways for understanding of genesis of influence of chemical elements on hematopoietic system is statistical processing of medical-biological data. 
The stage of mathematic processing is an obligatory one in the structure of scientific research $[4,6,7]$. Biological object, studied with use of measurements or calculations that is from quantitative side, for more or less exact assessment of its qualitative state, is a subject of biometry. At that mass phenomena, in which sphere statistical laws manifest their action, are taken into account [5].

Toxic injury of the bone marrow (myelotoxicity) or toxic injuries of lymph organs can appear as a result of direct action of the chemical substance on hematopoietic tissues. The specific toxicity is characterized with sudden, radical decrease of circulating blood cells and can also influence the bone marrow [8].

Steam cells are the key object of ecological toxicants. In the work [9] was conducted research of adult human steam cells for revelation of biomarkers of heavy metals influence. For this aim the cultures of cells, separated from cord blood were influenced by Cr (VI) or Cd during 48 hours. Experiments demonstrated the significant loss of cells. The processed cells did not demonstrate morphological signs of apoptosis - totality of cellular processes that lead to the death of cell [10, 11].

Compounds that include heavy metals and metalloids are causes of such biochemical effects as protein denaturation, changes of acid-base and ion balance and can favor the nervous toxicity [12]. The wide use of compounds that contain heavy metals and metalloids leads to professional risks. The question of potential risk at inhalation of welding smoke, that can accelerate the beginning of Parkinson's disease or even cause it, was raised last years. This question needs further research [13]. In the work [14] was proved the role of heavy metals as one of main harmful influence factors on human organism. There were considered parameters of the examination of heavy metals content in biosubstrates (blood and urine) of studied persons. There were studied correlations between profession and signs of disease of different classes.

With the help of simultaneous registration of the degree of injury on nuclear DNA and frequency of appearance of microkernels in peripheral blood cells can be carried out an assessment of genotoxic action of gas welding aerosols [15].

Thus, although connection between chemical elements and pathological disorders is evidently traced, often there are no undisputed proofs of influence of concrete element on pathogenesis of concrete disease. The question of analysis of influence of anthropogenic factors on marrowy hematosis stays open.

\section{Aim of research}

To study assessment of possibility to use existent mathematical methods for elaboration of data of medical studies for revelation of influence of concentration level of biogenic and abiogenic elements in human organism on hemopoiesis processes.

\section{Materials and methods of research}

Chemical elements that enter in human organism are accumulated in biomediums (hair, nails and blood) of patient; their quantitative values can be used as biological markers of the state of environment [2].

For the research were selected 48 dwellers of Dneprodzerzhinsk city (Ukraine), in whose biomediums were registered microelements.

The cellular indices, received using the method of leukoconcentrate of venous blood (LVB) [16]. Method of human LVB that gives the full panoramic presentation of cellular content of marrowy hematosis was firstly elaborated by R. A. Pospelova in laboratory of I. A. Kassirsky [17]. In further this methodology was improved by professor A. A. Prykhodchenko [18].

The essence of method is in concentration of nuclear elements of venous blood with further microscopy of dry fixed and colored smears of leukoconcentrate, study of cellular morphology and differential calculation of their percentage content.

LVB method can be used for the study of steam hematopoietic cell and also for diagnostics of bone marrow diseases. On the Fig. 2 is presented microfoto of leukoconcentrate of human venous blood where are present the cells of myeloid range. 


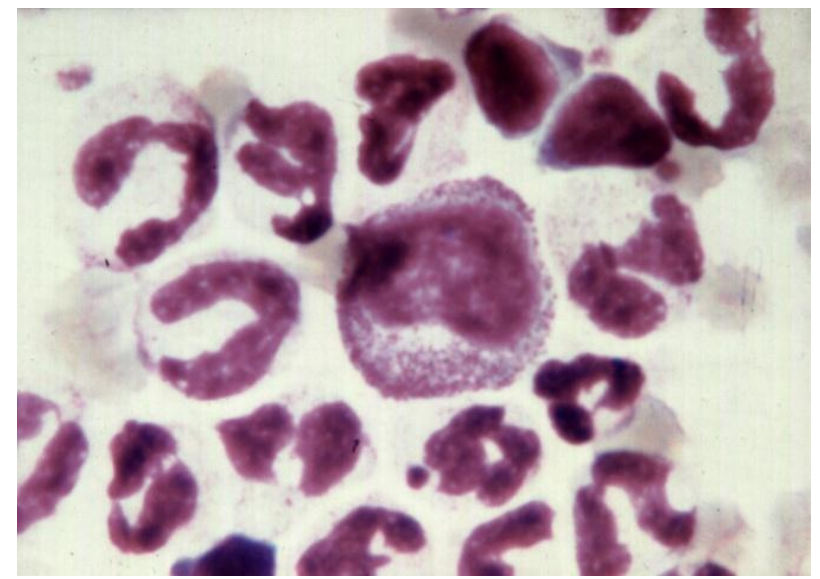

Fig. 2. LVB: in center progranulocyte, at left - stick-nuclear leukocytes, below - segment-nuclear leukocytes. Magnification $100 \times 7$. Coloration according to Romanovsky-Gimze

The most typical disorders in the blood system of patients were: destabilization in the system of immunocompetent cells and appearance of blast elements in venous blood. From the large number of cellular parameters of leukograms are selected the middle lymphocytes as competent cells that reflect the state of human immune system and blast cells which presence in human blood indicates problems with bone marrow. Methodical possibilities of LVB are given on the Fig. 3.

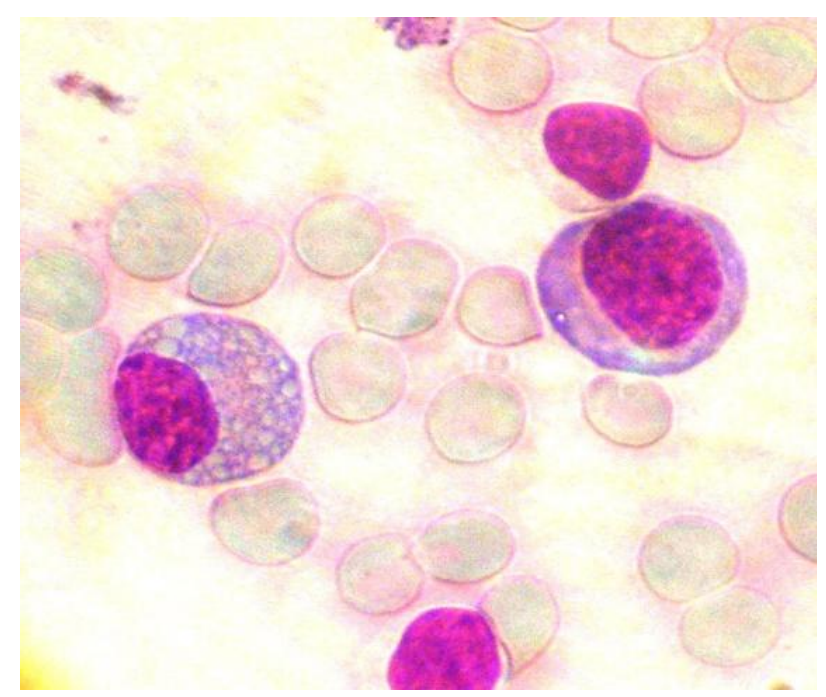

Fig. 3. Human LVB. At left - plasmatic cell, at right - undifferentiated blast cell

Atomic-emissive spectrographic determination of microelements in ashes of biopsy materials was carried out on the base of arch argon two-current plasmatron, specially adapted to the clinic material by analytic methods. Preparation of samples was carried out by evaporation to the wet salts and their further dissolution in $2-3 \mathrm{ml}$ of $1 \mathrm{~N}$ hydrochloric acid [18, 19]. For verification of analytic methods of determination of specific components in human blood serum can be used the referential material, given in [20].

Among chemical elements for the study were selected aluminum, chromium, lead and niobium. Because they have the expressed negative influence on human organism: aluminum is immunotoxin, hexavalent chromium has carcinogenic properties, lead is hematotropic and niobium causes disorders in blood system.

From the point of view of mathematical statistics, the study of separate statistical objects allows get the useful information about them and describe them by standard indices. At that the 
studied totality can be presented as a row of distribution by ranging (in order of growing or decrease of analyzed quantitative sign), give characteristic to this totality, indicated the central values of row (arithmetical mean, median, mode), scale of variation, form of distribution curve [21]. This kind of information can be enough in case when we deal with one-dimensional data about each unit of totality (for example, about one patient). But if we analyze two-dimensional data (for example, as in our case chemical elements or blood parameters) there is always a possibility to study each dimension separately - as a part of one-dimensional data totality. But the real effect can be attained at common study of both parameters. The main function of such approach is a possibility of revelation of connection between parameters. So, except traditional measurements and further calculations at analysis of statistical data we must solve also the problem of higher level - revelation of functional dependence between influence factor and registered (studied) value.

The procedure of search for supposed dependence between the different numerical totalities usually includes the following stages: establishing of significance of connection between them; possibility to give this dependence in the form of thematic expression (regression level). Correlative analysis allows make conclusion about the strength of interconnections between the pairs of data (x, y) and regressive analysis is used for prognostication of one variable (y) on the base of other (x) on the base of trend line.

Conventionally can be divided the methods that allow assess the presence of connection qualitatively and the ones that give quantitative assessments. To reveal the qualitative correlation between two studied numerical sets of experimental data there are different methods that are commonly named elementary ones. It can be techniques, based on the following operations: parallel comparison of rows; construction of correlative and group tables; graphic presentation using correlation field. The other method that is more complicated and statistically reliable it is quantitative assessment of connection using calculation of correlation coefficient and its statistical verification.

Regressive analysis was used in work. $\mathrm{Y}$ is indices of leukogram of venous blood, namely middle leukocytes (A3), sum of blast cells (B), and factors $\mathrm{X}$ are chemical elements (compounds of aluminum, chromium, niobium, lead) in blood serum.

Among pair regressions the most spread, studied and simple in modeling practice is pair linear regression that allows reveal causal relations. It must be differed the stochastic dependence and functional one. At stochastic dependence one factor value can correspond to the several index values. At functional dependence one argument value corresponds to only one function value [21, 22].

In the work was carried out verification of working hypothesis: there is stochastic linear dependence between index Y and factor X. For that the effectiveness of model of linear regression was considered. We have $\mathrm{n}$ pairs of independent observations, expressed as multitude of points in Descartes system of axes. The essence of problem is to find in Descartes system of axes the smoothing line that passes through the given multitude of points in a "best" way.

\section{Results of research}

The study of possibility to use the standard approaches we realize on example of data on concentration of aluminum compounds and indices of percentage content of blast cells and middle lymphocytes. For the study of aluminum influence on hemopoiesis were selected the data of 46 persons, because in 2 of 48 studied person aluminum was not detected. Let's construct correlative field of studied data of dependence of percentage content of blast cells in leukoconcentrate of venous blood from concentration of aluminum compound in blood serum (Fig. 4).

The constructed diagrams demonstrate the data concentration in interval from $0,74 \mathrm{mkg} / \mathrm{g}$ to $26,5 \mathrm{mkg} / \mathrm{g}$ that at the first sight indicates dependence of the level of lymphoid and blast cells from aluminum concentration in human organism; the higher concentration of aluminum compounds, the lower level of lymphoid elements and blast cells in venous blood. This working hypothesis is verified by the method of graphic visualization through the construction of column diagram. Comparison of data of percentage content of the middle lymphocytes and blast cells at growth of aluminum concentration in blood is presented on the Fig. 5. 


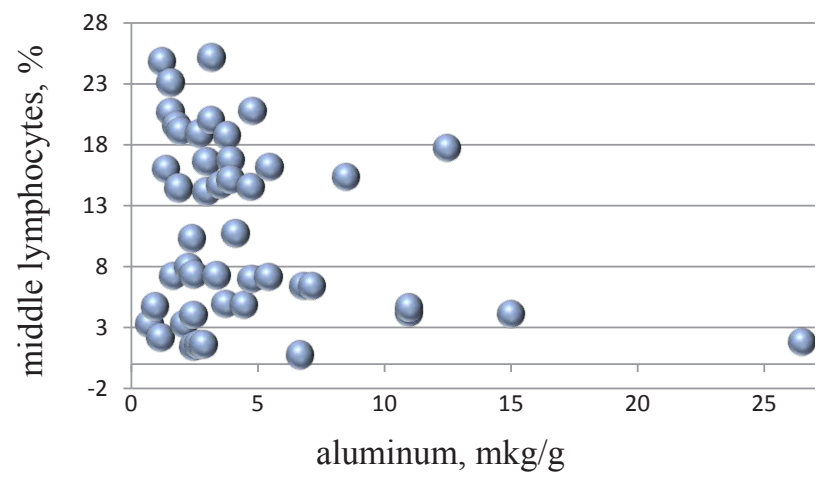

$a$

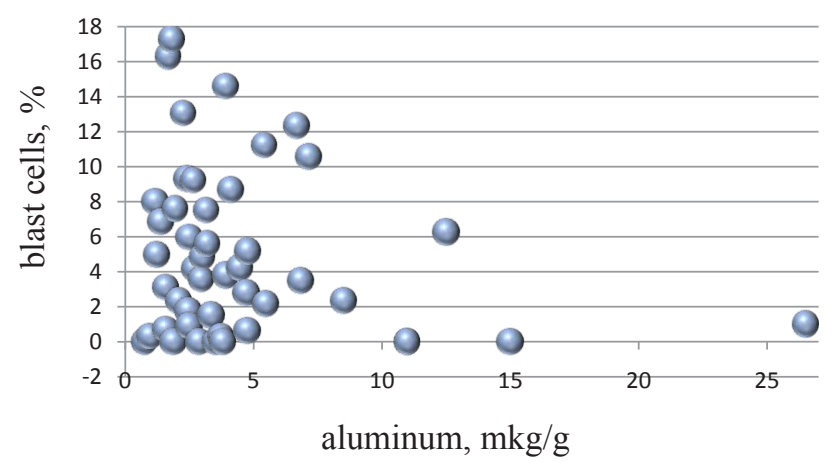

$b$

Fig. 4. Diagram of diffusion of data by aluminum concentration in blood serum: $a$ - for middle lymphocytes, $b$ - for blast cells

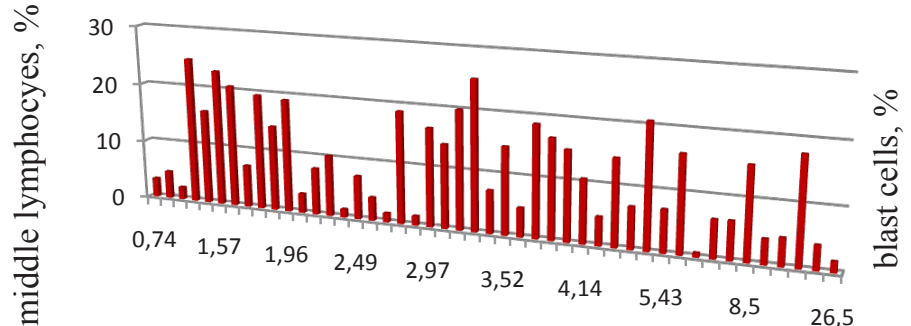

aluminum, $\mathrm{mk} / \mathrm{g}$

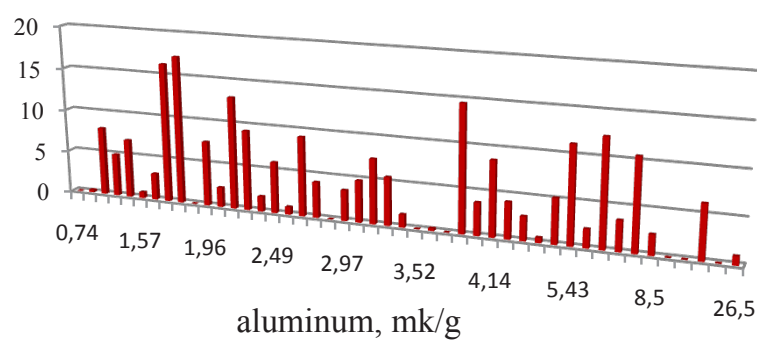

$b$

Fig. 5. Diagrams of dependence of percentage number of middle lymphocytes $(a)$ and blast cells $(\sigma)$ in venous blood from concentration of aluminum compounds in blood serum

Diagrams don't allow make conclusion about supposed dependence. At the same time it is observed on the separate intervals. Studying the possible variants for regression line, we get the most index of reliable approximation for polynomial curve of sixth order (Fig. 6).

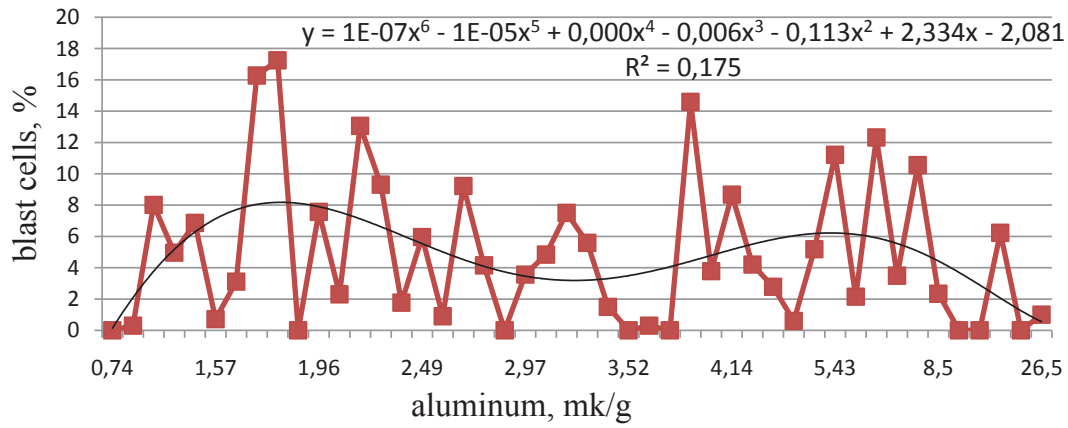

Fig. 6. Construction of regression line on the graph of dependence of sum of blast cells from aluminum concentration in blood serum

The value of reliable approximation $\mathrm{R}^{2}$ allows represent or hide the value of reliable approximation that is automatically calculated by Microsoft Office Excel for determination of degree of reliability of regression line.

Approximation is reliable at $\mathrm{R}^{2} \geq 0,8$. In our cases for initial data for polynomial trend line of maximal $6^{\text {th }}$ degree $\mathrm{R}^{2}$ does not exceed 0,3 , and for linear approximation even less: $\mathrm{R}^{2}=0,018$. Analogous results we have also for the middle lymphocytes (Table 1). 
Calculated coefficients of correlation $\mathrm{r}$ and maximal coefficients $\mathrm{R}^{2}$ among possible regression lines for dependence of percentage value of the number of middle lymphocytes and blast cells for all four studied microelements are presented in the Table $\mathbf{1 .}$

Table 1

Calculations of coefficient indices of correlation (r) and regression $\left(\mathrm{R}^{2}\right)$

\begin{tabular}{cccccccc}
\hline & \multicolumn{2}{c}{ Aluminum } & \multicolumn{2}{c}{ Chromium } & \multicolumn{2}{c}{ Niobium } & \multicolumn{2}{c}{ Lead } & $\mathbf{R}^{2}$ & $\mathbf{R}^{2}$ & $\mathbf{R}^{\mathbf{2}}$ \\
\hline Middle lymphocytes & $-0,25$ & 0,31 & $-0,13$ & 0,13 & 0,13 & 0,25 & 0,28 \\
Blast cells & $-0,2$ & 0,18 & $-0,2$ & 0,18 & 0,10 & 0,21 & 0,08
\end{tabular}

\section{Discussion of results}

Analysis of calculations of correlation coefficients testifies to the same character of influence of chemical elements on the cellular blood parameters. Thus, the level of aluminum and blast cells and middle lymphocytes has the reverse dependence: the higher level of aluminum compounds, the lower percentage number of aforesaid blood cells.

The research allows make conclusion that traditional methods of statistical data processing such as finding of mode, median and mean value cannot be used for revelation of mutual dependence between concentration of chemical elements in blood serum and percentage content of venous blood cells, because they can be used only for one-dimensional data blocks. The use of whole sampling of correlative and regressive analysis does not give us a possibility to make reliable conclusion about the role of studied chemical elements for hemostasis processes. The received results demonstrate weak interconnection between factor and index. At the same time the column diagrams allow made assumptions about dependence on separate intervals.

It causes the necessity of elaboration of new approaches on the base of analysis of index behavior on separate intervals for revelation of dependence of the blood cellular content from the level of concentration of chemical elements in it.

\section{Conclusions}

1. The cells of venous blood reflect the state of bone marrow and can be chosen as cells-targets for the study of influence of chemical elements on hemopoiesis system. Aluminum, chromium, niobium, lead compounds are anthropogenic factors that potentially influence the human hemopoiesis.

2. Visualization of input data by the way of construction of diffusion diagrams and column ones allow make conclusion about the dependence of levels of immunocompetent cells of blast elements from microelements concentration in human biomediums that can testify to the influence of biogenic microelements on the human hemopoiesis system.

3. The processing of data of system "microelement-cell" by the traditional methods of mathematical statistics such as correlative and regressive analysis does not give a possibility to reveal the influence of chemical elements on human hemopoiesis processes. That is why for revelation of formulated problem it is necessary to elaborate the new approaches and methods of research.

\section{References}

[1] Noli, F., Tsamos, P. (2016). Concentration of heavy metals and trace elements in soils, waters and vegetables and assessment of health risk in the vicinity of a lignite-fired power plant. Science of The Total Environment, 563-564, 377-385. doi: 10.1016/j.scitotenv.2016.04.098

[2] Das, S., Raj, R., Mangwani, N., Dash, H. R., Chakraborty, J. (2014). Heavy Metals and Hydrocarbons. Microbial Biodegradation and Bioremediation, 23-54. doi:10.1016/b978-0-12-800021-2.00002-9

[3] Ibrahim, D., Froberg, B., Wolf, A., Rusyniak, D. E. (2006). Heavy Metal Poisoning: Clinical Presentations and Pathophysiology. Clinics in Laboratory Medicine, 26 (1), 67-97. doi: 10.1016/j.cll.2006.02.003

[4] Antamonov, M. Yu. Matematicheskie aspekty analiza dannyh v medico-ekologicheskih issledovaniyah. Aviailableat: http://www.health.gov.ua/publ/conf.nsf/50e0ce97d91c75b3c2256d8f0025c386/c2e9d1e8ae70d844c2256dc6003f7ea3?OpenDocument

[5] Lakin, G. F. (1990). Biometriya. Moscow: Vyshayashkola, 352. 
[6] Antamonov, M. Yu. (2006). Matematicheskaya obrabotka I analiz medico-biologicheskih dannyh. Kyiv: Malydruk, 558.

[7] Pashinska, S. L., Antamonov, M. Yu. (2014). Tehnologiya rozrahunku ta analizu integralnyh pokaznykiv dlia ocinky ekologo-gigienichnyh ob'ektiv. Molody vcheny. Biologichni nauky, 8 (11), 10-12.

[8] Haschek, W. M., Rousseaux, C. G., Wallig, M. A. (2010). Hematopoietic System. Fundamentals of Toxicologic Pathology, 491-512. doi: 10.1016/b978-0-12-370469-6.00016-7

[9] Di Gioacchino, M., Petrarca, C., Perrone, A., Farina, M., Sabbioni, E., Hartung, T. et. al. (2008). Autophagy as an ultrastructural marker of heavy metal toxicity in human cord blood hematopoietic stem cells. Science of The Total Environment, 392 (1), 50-58. doi: 10.1016/j.scitotenv.2007.11.009

[10] Kroemer, G., Galluzzi, L., Vandenabeele, P., Abrams, J., Alnemri, E. S., Baehrecke, E. H. et. al. (2008). Classification of cell death: recommendations of the Nomenclature Committee on Cell Death 2009. Cell Death and Differentiation, 16 (1), 3-11. doi: 10.1038/cdd.2008.150

[11] Kerr, J. F. R., Wyllie, A. H., Currie, A. R. (1972). Apoptosis: a basic biological phenomenon with wide-ranging implications in tissue kinetics. British Journal of Cancer, 26 (4), 239-257.

[12] Cohen, M. M. (1980). Neurotoxic effects of heavy metals and metalloids. Biochemistry of Brain, 453-468. doi: 10.1016/b978-0-08-021345-3.50020-4

[13] Huang, C.-C. (2007). Parkinsonism Inducedby Chronic Manganese Intoxication - An Experience in Taiwan. Chang Gung Med Journal, 30 (5), 385-395.

[14] Shafran, L. M., Gozhenko A. I. (2009). Professionalno obuslovlenye metallonefropatii na transporte: etiopatoginez, diagnostika, profilaktika. Bulleten VCNC SO RAMN, 1 (65), 141-146.

[15] Tomilin, N. V., Petrov, A. N., Filko, O. A., Khrabrova, A. V., Solovyeva, N. E., Ivanova, T. M. et. al. (2015). Ocenka stepeni povrezhdeniya yaderniy DNK v kletkah perefericheskoy krovi ludey proffesionalno sviazanyh s deystviem tiazhelyh metallov. Organizacija zdravohranienija, 16, 383-392. Available at: http://www.medline.ru/public/art/tom16/art37.html

[16] Kasirski, I. A., Alekseev, G. A. (1955). Klinicheskaya gematologia. Moscow: Medgiz, 720.

[17] Pospelova, R. A. (1973). Leykokoncentracia v klinicheskoy praktike, diagnosticheskoe znacenie. Moscow: Medicina, 21.

[18] Prihodchenko, A. A. (1992). Issledovanie leykokoncentratia venoznoy krovi v klinicheskoy ekologii. Metodika issledovatelskaya. Moscow: NPO «Vektor», 28.

[19] Yaderno-fizicheskie metody. Instrukcia № 194 - YaF. (1982). Rentgenoradiometricheskoe opredelenie elementov s primeneniem poluprovodnikovogo spektrometra. Moscow: VIMS, 21.

[20] Trace element reference materials for clinical research and diagnostics. Available at: http:// www.lgcstandards.com/ZR/en/

[21] Gmurman, V. E. (2001). Teoriya veroyatnostey I matematicheskaya statistika. Moscow: Vyshayashkola, 479.

[22] Tolbatov, Yu. A. (1997). Ekonometrika. Kyiv: Chetvertahvylia, 320. 